\title{
Gene Identification and Characterization of the Pyridoxine Degradative Enzyme $\alpha$-(N-Acetylaminomethylene)succinic Acid Amidohydrolase from Mesorhizobium loti MAFF303099
}

\author{
Baiqiang YuAn ${ }^{1}$, Nana YoKochi ${ }^{1}$, Yu YoshiKANE ${ }^{1}$, Kouhei OHNISHI ${ }^{2}$, Fei GE ${ }^{1}$, \\ and Toshiharu YAGI ${ }^{1, *}$ \\ ${ }^{1}$ Department of Bioresources Science, Faculty of Agriculture, and ${ }^{2}$ Research Institute of Molecular Genetics, \\ Kochi University, Nankoku, Kochi 783-8502, Japan
}

(Received November 7, 2007)

\begin{abstract}
Summary We have found for the first time that a chromosomal gene, mlr6787, in Mesorhizobium loti encodes the pyridoxine degradative enzyme $\alpha$-(N-acetylaminomethylene)succinic acid (AAMS) amidohydrolase. The recombinant enzyme expressed in Escherichia coli cells was homogeneously purified and characterized. The enzyme consisted of two subunits each with a molecular mass of 34,000 $\pm 1,000 \mathrm{Da}$, and exhibited $\mathrm{Km}$ and kcat values of $53.7 \pm 6 \mu \mathrm{M}$ and $307.3 \pm 12 \mathrm{~min}^{-1}$, respectively. The enzyme required no cofactor or metal ion. The primary structure of AAMS amidohydrolase was elucidated for the first time here. The primary structure of the enzyme protein showed no significant identity to those of known hydrolase proteins and low homology to those of fluoroacetate dehalogenase (PDB code, 1Y37), haloalkane dehalogenase (1K5P), and aryl esterase (1VA4).
\end{abstract}

Key Words vitamin $\mathrm{B}_{6}$, pyridoxine, degradation pathway, $\alpha$ - $(\mathrm{N}$-acetylaminomethylene)succinic acid, amidohydrolase

$\alpha$-(N-Acetylaminomethylene)succinic acid (AAMS) amidohydrolase catalyzes degradation of AAMS, which is produced from 2-methyl-3-hydroxypyridine-5-carboxylic acid (MHPC) dioxygenase as shown in Fig. 1A, to acetic acid, ammonia, carbon dioxide, and succinic semialdehyde as shown in Fig. 1B. The enzyme reaction is the final step in degradation pathway I for vitamin $\mathrm{B}_{6}$ (pyridoxine, pyridoxamine, and pyridoxal) (1). The enzyme was purified from the crude extract of Pseudomonas MA-1 cells grown on pyridoxine as a sole carbon source, and some properties were characterized $(2,3)$. However, the primary structure of the enzyme or the gene encoding the enzyme has not been reported.

Recently we found that a nitrogen-fixing symbiotic bacterium, Mesorhizobium loti MAF303099 possessed several enzymes involved in degradation pathway I, and characterized their properties. The first enzyme for degradation of pyridoxine is pyridoxine 4-oxidase $(4,5)$ and that for pyridoxamine is pyridoxamine-pyruvate aminotransferase (6). The second, third, seventh enzymes are pyridoxal 4-dehydrogenase (7), 4-pyridoxolactonase (8), and MHPC dioxygenase (9), respectively. These enzymes are encoded by genes (from mll6785 to mlr6807) clustered on the chromosome of the bacterium. The numbering of the genes is described in the RhizoBase (10). Among the enzymes in the cluster, gene mlr6787 is the only one which can be deduced to be a hydrolase based on the predicted amino acid sequence.

*To whom correspondence should be addressed.

E-mail: yagito@kochi-u.ac.jp
Here, we identified the protein encoded by the mlr6787 gene as the AAMS amidohydrolase, and elucidated the primary structure of the enzyme for the first time. The recombinant AAMS amidohydrolase was over-expressed and characterized.

\section{MATERIALS AND METHODS}

Bacterial strains, plasmids and chemicals. Escherichia coli strains BL21(DE3) and JM109 were purchased from Novagen (San Diego, USA). M. loti MAFF303099 was obtained from MAFF GenBank (Tsukuba, Japan). The plasmids pTrc99A (Pharmacia Biotech, Uppsala, Sweden), pTA2 (TOYOBO, Osaka, Japan), pNEB205A (New England BioLabs, Beverly, USA), pET-21a (Novagen), and pKY206 (11) were used for cloning and expression. MHPC was prepared from the culture media of $M$. loti as described previously (9). AAMS was prepared from MHPC by bioconversion with recombinant $E$. coli cells as described below.

Preparation of the recombinant $E$. coli cells for bioconversion of MHPC to AAMS, and preparation of AAMS. As shown in Fig. 1A, AAMS was produced from MHPC by a dioxygenation reaction catalyzed by MHPC dioxygenase. The reaction uses NADH as a hydrogen donor. Thus, the regeneration system of NADH was required to make the conversion reaction complete. An ethanolactive medium-chain dehydrogenase/reductase alcohol dehydrogenase (12) gene (adh) was amplified by PCR with the chromosomal DNA from E. coli K12 as a template, and primers 5'-GGAGACAdUATGAAGGCTGCAG TTGTTACGAAGG-3' (primer adh-F1, the boldfaced letters show NdeI restriction site) and 5'-GGGAAAGdUTT 
A

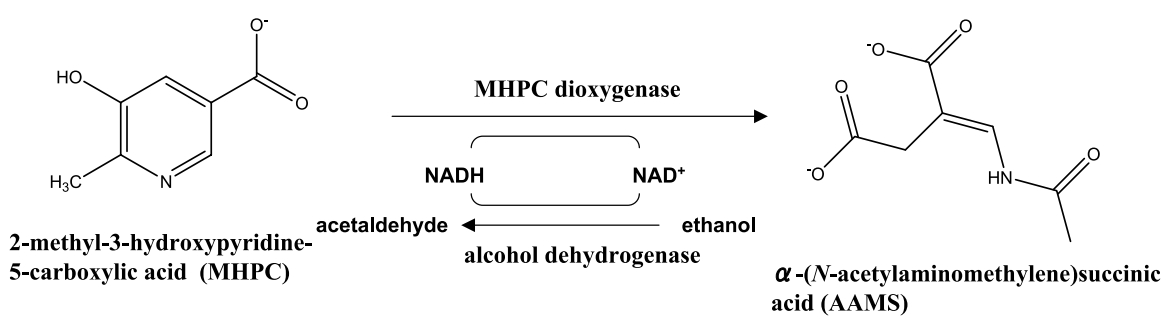

B

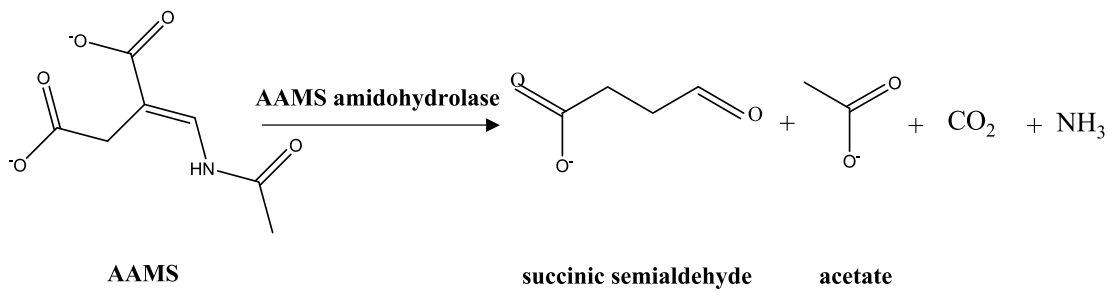

Fig. 1. A: the principle of bio-synthesis of AAMS with recombinant E. coli cells. B: the reaction catalyzed by AAMS amidohydrolase.

AGTGACGGAAATCAATCACCATGC-3'(primer adh-R1). The reaction mixture $(50 \mu \mathrm{L})$ for PCR consisted of LA PCR Buffer II, $20 \mathrm{nmol}$ dNTP, 2.5 U LA Taq polymerase, $125 \mathrm{nmol} \mathrm{MgCl}_{2}, 3.8 \mathrm{ng}$ of the template DNA, and $20 \mathrm{pmol}$ of each primer. The PCR condition was heating to $94^{\circ} \mathrm{C}$ for $5 \mathrm{~min}, 30$ cycles of $94^{\circ} \mathrm{C}$ for $1 \mathrm{~min}, 54.5^{\circ} \mathrm{C}$ for $1 \mathrm{~min}$, and $72^{\circ} \mathrm{C}$ for $1 \mathrm{~min}$. The PCR product was ligated with a USER ${ }^{\mathrm{TM}}$ FRIENDLY Cloning Kit into the pNEB205A, to construct pNEB205A-adh. After the sequence of the introduced fragment had been verified by DNA sequencing of cloned adh gene with an ABI PRISM 3100 genetic sequencer, pNEB205A-adh was digested with NdeI and EcoRI, and adh gene was recloned into the NdeI and EcoRI sites of pET21a. The constructed plasmid was designated as pET21a-adh. The plasmid pET21a-adh was digested with XbaI and HindIII, and the DNA fragment containing the adh gene was isolated from an agarose gel. The isolated fragment was ligated into pTrc99A to make pTrc99A-adh. pET6788 plasmid harboring MHPC dioxygenase gene (9) was digested with EcoRI, and then subjected to alkaline phosphatase treatment. The pTrc99A-adh was digested with EcoRI, and then the adh gene isolated from an agarose gel was inserted into the EcoRI site of pET6788 to construct pET6788-adh. E. coli BL21(DE3) cells were co-transformed with pET21a-adh-pld and pKY206 carrying the groES and groEL genes encoding chaperonins (11). The transformed cells were used for the bioconversion.

The cotransformed cells $(100 \mathrm{mg})$ were incubated at $30^{\circ} \mathrm{C}$ for $24 \mathrm{~h}$ in $1 \mathrm{~mL}$ of $50 \mathrm{~mm}$ potassium phosphate buffer ( $\mathrm{pH} 7.5$ ) containing $0.5 \mathrm{M}$ ethanol and $5 \mathrm{~mm}$ MHPC. Then the reaction mixture was applied to an ion-exchange HPLC column IEC QA825 $(8.0 \times 75 \mathrm{~mm})$ (Showa Denko, Tokyo, Japan). The AAMS was eluted at $0.2 \mathrm{M}$ formic acid by linear gradient $(0-0.5 \mathrm{M}$ formic acid) elution. The formic acid in the elution was removed thoroughly by evaporation at $60^{\circ} \mathrm{C}$ and then AAMS was crystallized from hot water. The AAMS preparation showed the same absorption spectrum as described previously (2). Its structure was verified by the NMR spectrum. Its concentration was determined with an extinction coefficient of $17.5 \mathrm{~mm}^{-1} \mathrm{~cm}^{-1}(\mathrm{pH}$ 7.0) at $261 \mathrm{~nm}$.

Cloning and expression of the mlr6787 gene. The mlr6787 gene was amplified by PCR from the chromosomal DNA of prepared M. loti MAFF303099. The primers used were 5'-CATATGGACATGGCGGCAGA CATA-3' (mlr6787-F) with a NdeI site (underlined) and a start codon (bold type), and 5'-GGATCCTCAGGCGTC TATGAAGTT-3' (mlr6787-R) with a BamHI site and a stop codon (bold type). PCR was performed in a $50-\mu \mathrm{L}$ reaction mixture containing KOD-plus buffer, $0.2 \mathrm{mM}$ dNTPs, $1.0 \mathrm{~mm} \mathrm{MgSO}_{4}, 0.3 \mu \mathrm{M}$ of each primer, $2 \mathrm{ng} M$. loti chromosome and 1.25 U KOD-plus DNA polymerase (TOYOBO). The reaction mixture was heated at $94^{\circ} \mathrm{C}$ for $2 \mathrm{~min}$, then subjected to 30 cycles of heating $\left(94^{\circ} \mathrm{C}\right.$, $15 \mathrm{~s} ; 55^{\circ} \mathrm{C}, 30 \mathrm{~s}$; and $\left.68^{\circ} \mathrm{C}, 90 \mathrm{~s}\right)$. Finally, the reaction mixture was heated at $68^{\circ} \mathrm{C}$ for $10 \mathrm{~min}$. The amplified DNA fragment $(846 \mathrm{bp}$ ) was cloned into the pTA2 vector, to construct pTA6787. After the sequence of the introduced fragment had been verified by DNA sequencing with an ABI PRISM 3100-Avant Genetic Analyzer (Applied Biosystems, Foster City, USA), pTA6787 was digested with NdeI and BamHI, and then the digested DNA fragment was inserted into the NdeI/BamHI sites of pET-21a to construct the expression plasmid pET6787.

E. coli BL21(DE3) cells were transformed with pET6787. The transformed cells were grown aerobically at $37^{\circ} \mathrm{C}$ in $5 \mathrm{~mL}$ of LB medium containing ampicillin $\left(50 \mu \mathrm{g} \mathrm{mL} \mathrm{m}^{-1}\right)$ until the absorbance at $600 \mathrm{~nm}$ reached 1.0. The broth was then added to $200 \mathrm{~mL}$ of the same medium, and the inoculated cells were grown 
at $37^{\circ} \mathrm{C}$ for $16 \mathrm{~h}$. The bacterial cells were harvested by centrifugation at $8,000 \times g$ for $10 \mathrm{~min}$ at $4^{\circ} \mathrm{C}$, washed with $0.9 \%(\mathrm{w} / \mathrm{v})$ sodium chloride, and then stored at $-20^{\circ} \mathrm{C}$ until use.

Purification of recombinant AAMS amidohydrolase. All steps were done at $4-10^{\circ} \mathrm{C}$. The transformant E. coli BL21(DE3)/pET6787 cells (5.5 g) were suspended in $25 \mathrm{~mL}$ of $50 \mathrm{mM}$ potassium phosphate buffer, $\mathrm{pH}$ 7.0, containing $0.1 \%(\mathrm{v} / \mathrm{v}) 2$-mercaptoethanol and $0.1 \mathrm{~mm}$ phenylmethysulfonyl fluoride) (Buffer A containing phenylmethylsulfonyl fluoride). The cell suspension was sonicated on ice for 6 min with a Heatsystems-Ultrasonics sonicator $\mathrm{W}-220$. After centrifugation at $10,000 \times g$ for $20 \mathrm{~min}$ at $4^{\circ} \mathrm{C}$, the supernatant $(44 \mathrm{~mL})$ was used as the crude extract. The crude extract was fractionated with ammonium sulfate, and the precipitate obtained on centrifugation of $40-55 \%$ saturated solution was dissolved in $15 \mathrm{~mL}$ of Buffer $\mathrm{A}$, and the solution was dialyzed thoroughly against Buffer A. To the dialyzed solution $(20 \mathrm{~mL})$ was added $1 \mathrm{M}$ ammonium sulfate, and then the enzyme solution was applied to a Butyl-Toyopearl $650 \mathrm{M}$ column $(3.0 \times 17.0 \mathrm{~cm}$, Tosoh Corporation, Tokyo, Japan) equilibrated with Buffer A containing $1 \mathrm{M}$ ammonium sulfate. The enzyme was eluted at around $0.4 \mathrm{M}$ ammonium sulfate with a linear gradient (1.0-0 M ammonium sulfate). The active fractions were pooled and dialyzed thoroughly against Buffer B (50 mM Tris-HCl, pH 7.0, containing $0.1 \%$ 2-mercaptoethanol). The dialyzed solution was applied to a hydroxylapatite column $(1.5 \times$ $16.0 \mathrm{~cm}$ ) equilibrated with Buffer B. The enzyme was eluted at around $10 \mathrm{~mm}$ potassium phosphate $(\mathrm{pH} 7.0)$ with a linear gradient (0-50 mM potassium phosphate). The active fraction was dialyzed thoroughly against $20 \mathrm{~mm}$ potassium phosphate buffer containing $0.1 \% 2$ mercarptoethanol and $10 \%$ glycerol, and used as the homogeneous enzyme preparation.

Enzyme and protein assays. AAMS amidohydrolase activity was determined by measuring the initial decrease in $A_{261}$ of AAMS at $25^{\circ} \mathrm{C}$ in a reaction mixture consisting of $50 \mathrm{mM}$ potassium phosphate buffer $(\mathrm{pH}$ 7.0), $0.025 \mathrm{mM}$ AAMS and the enzyme. One unit of enzyme was defined as the amount of enzyme that catalyzed the hydrolysis of $1 \mu \mathrm{mol}$ of the substrate per min. The substrate concentration was near the $\mathrm{Km}$ value to make the original absorbance at $261 \mathrm{~nm}$ precisely measurable. The optimum $\mathrm{pH}$ of the enzyme was determined with a $100 \mathrm{mM}$ GTA buffer ( $\mathrm{pH}$ 5.49-8.50), which is a universal one consisting of $33.3 \mathrm{~mm} 3,3-$ dimethylglutaric acid, $33.3 \mathrm{~mm}$ Tris, and $33.3 \mathrm{~mm} 2-$ amino-2-methyl-1,3-propanediol.

Protein concentration was measured by the dyebinding method with bovine serum albumin as a standard (13). The concentration of the purified enzyme was also determined from the molecular absorption coefficient $\left(\varepsilon=23,040 \mathrm{M}^{-1} \mathrm{~cm}^{-1}\right)$ at $280 \mathrm{~nm}$ determined on the basis of the amino acid composition (14). The reaction conditions for measuring the effect of $\mathrm{pH}$ and temperature on the enzyme activity are shown in the legends of the figures.
When the effect of metal ions on enzyme activity was determined, the enzyme was incubated with $10 \mathrm{~mm}$ EDTA on ice for $3 \mathrm{~h}$ and then the incubated solution was applied to a Sephadex G25 column (PD-10, GE Haelthcare). The eluted enzyme solution was incubated with $1 \mathrm{mM}$ of $\mathrm{Zn}^{2+}, \mathrm{Fe}^{2+}$ or $\mathrm{Ni}^{2+}$ at $30^{\circ} \mathrm{C}$ for $1 \mathrm{~h}$, and then the activity was assayed.

Other analytical methods. The molecular masses of the native enzyme and the subunit were determined by gel filtration and SDS-PAGE, respectively, as described previously (7). The N-terminal amino acid sequence of the recombinant enzyme was determined with an Applied Biosystems 492 protein sequencer. NMR spectrum was measured with a Varian MERCURY 300 spectrophotometer.

\section{RESULTS AND DISCUSSION}

Preparation of AAMS with the recombinant E. coli cells

The time course of bioconversion of MHPC to AAMS was spectrophotometrically followed. MHPC with absorption maximum at $241 \mathrm{~nm}\left(3.7 \mathrm{mM}^{-1} \mathrm{~cm}^{-1}\right)$ in $0.1 \mathrm{M} \mathrm{HCl}$ was completely changed to AAMS with that at $265 \mathrm{~nm}\left(21.3 \mathrm{mM}^{-1} \mathrm{~cm}^{-1}\right)$ after $24 \mathrm{~h}$ under the reaction conditions described above. Then, AAMS in the reaction mixture was purified and crystallized. The over-all yield of AAMS was about $15 \%$.

Molecular cloning and expression of the mlr6787 gene

The E. coli BL21(DE3) cells transformed with the expression plasmid, pET6787, grown at $37^{\circ} \mathrm{C}$ showed high AAMS amidohydrolase activity: the activity $(0.38 \pm 0.13 \mathrm{U} / \mathrm{mg})$ was about 42 -fold higher than the value for $M$. loti cells grown in the synthetic medium

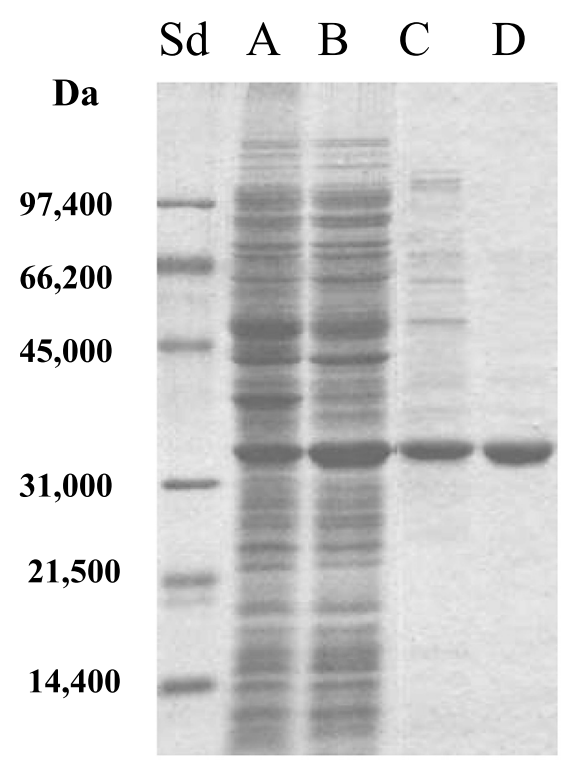

Fig. 2. SDS-PAGE patterns of the crude extract and the purified enzyme fractions from E. coli BL21(DE3)/ pET6787 cells. Lane A, cell extract $(20 \mu \mathrm{g})$; lane B, 40$55 \%$ saturated ammonium sulfate fraction $(20 \mu \mathrm{g})$; lane $\mathrm{C}$, the fraction $(5.0 \mu \mathrm{g})$ from the Butyl-Toyopearl column chromatography; lane $\mathrm{D}$, the fraction $(2.8 \mu \mathrm{g})$ from the hydroxylapatite column chromatography. The standard proteins were applied to lane Sd. 
Table 1. Purification of AAMS amidohydrolase from the transformant E. coli cells.

\begin{tabular}{lcccc}
\hline \multicolumn{1}{c}{ Fraction } & Total protein $(\mathrm{mg})$ & Total activity $(\mathrm{U})$ & Specific activity (U/mg) & Yield (\%) \\
\hline Crude extract & 654 & 306 & 0.468 & 100 \\
Ammonium sulfate & 370 & 263 & 0.711 & 83.6 \\
Butyl-Toyopearl & 57.4 & 65.0 & 1.14 & 21.0 \\
Hydroxylapatite & 20.9 & 38.7 & 1.89 & 12.4 \\
\hline
\end{tabular}

MDMAAD I ASDHF I SRRVDI GR I ILNVREKGSGPLMLFFHG I TSNSAVFEPLMIRLSDR-FIT I AVDQRGHGLSDKPE-----TGYEANDYADDIAGL IRTLARGH

AAMSAH - $\quad$ AILVGHSLGARNSVTAAAKY-----PDLVRSVVAIDFTPYIETEALDALEARVNAGSQLFEDIKAVEAYLAGRYPNIPADAIRIRAESGYQP-----VDGGLR AryIE -VTLVGFSMGGGDVARYIARHGSARVAGLVLLGAVTPLFGQKPDYPQGVPLDVFARFKTELLKDRAQFISDDFNAPFYGINK--GQVVSQGVQTQ-----TLQIAL -VVLVGFSMGTGELARYVARYGHERVAKLAFLASLEPFLVQRDDNPEGVPQEVFDG I EAAAKGDRFAWFTDFYKNFYNLDENLGSR I SEQAVTG-----SWNVA I RVVLVVHDWGSALGFDWARRHRERVQG I AYMEA I AMP I EWADFPEQDRDLFQAFRSQAGEELVLQDNVFVEQVLPGL ILRPLSEAEMAAYREPF----LAAGEAR

AAMSAH PLASSAAMAQTARGLRSDLVPAYRDVTKP---VLIVRGESSKLVSAAALAKTS-RLRPDLPVVVVPGA-DHYVNEVSPEITLKAITNFIDALASLKATVDCVTAFAETDFRPDMAK I DVP--- TLVIHGDGDQIVPFETTGKVAAEL I KGAELKVYKDA-PHGFAVTHAQQLNEDLLAFLKRGSHHHHHH-

$\gamma$ Lac GSAPVAAYAVVPAWIE-DFRSDVEAVRAAGKPTLILHGTKDNILPIDATARRFHQAVPEADYVEVEGA-PHGLLWTHADEVNAALKTFLAK-

FADH PAAIHGSCCDYRAGGT IDFELDHGDLGRQVQCPALVFSGSAGLMHSLFEMQVVWAPRLANMRFASLPG-GHFFVDRFPDDTARILREFLSDARSG IHQTERRES HADH RPTLSWPRQIPI AGTPADVVA I ARDYAGWLSESPI PKLF INAEPGALTTGRMRDFCRTWPNQTEI TVAGAHF I QEDSPDE I GAAI AAFVRRLRPA-

Fig. 3. The primary and predicted secondary structures of AAMS amidohydrolase, and alignment of amino acid sequences of the enzyme and some other similar enzymes. In the sequence of AAMS amidohydrolase (AAMSAH), the amino-terminal amino acid residues determined by the sequencer, and $\beta$-sheet and $\alpha$-helix structures predicted by JPRED are shown by underlined, double-underlined, and wave-underlined letters, respectively. The secondary structures determined in aryl esterase (ArylE) from $P$. fluorescens are marked in the same way as those for AAMSAH. The amino acids involved in the catalytic triad in aryl esterase are shown in red letters. $\gamma$-Lactamase $(\gamma \mathrm{Lac})$ from Aureobacterium sp., fluoroacetate dehalogenase (FADH) from Burkholderia sp., and haloalkane dehalogenase (HADH) from Sphingomonas paucimobilis are aligned together. Amino acid residues common in 5 sequences are shown in blue letters.

containing pyridoxine. The E. coli cells transformed with pET21a showed no measurable AAMS amidohydrolase activity. Thus, mlr6787 gene encodes AAMS amidohydrolase.

Purification and properties of the recombinant AAMS amidohydrolase

The recombinant AAMS amidohydrolase was purified to homogeneity from the transformed E. coli by the ammonium sulfate fractionation and two steps of column chromatography (Fig. 2 and Table 1). The purified enzyme preparation gave a single protein band corresponding to a molecular weight of $34,000 \pm 1,000$ (an average of three experiments \pm SD) on SDS-PAGE. The value was slightly higher than that $(\mathrm{Mr}=29,896)$ of the predicted protein encoded by mlr6787 gene. The molecular weight of the native enzyme was found to be $64,000 \pm 2,000$ on gel filtration. The amino terminal 10-amino acid sequence was MDMAADIASD, coinciding with that deduced from the nucleotide sequence of the mlr6787 gene. Thus, the enzyme was a dimeric protein.

The primary structure and predicted secondary structure of AAMS amidohydrolase is shown in Fig. 3. The recombinant enzyme consisted of 273 amino acid residues. The predicted secondary structure contained $8 \beta$-strands and $9 \alpha$-helixes.

The optimum $\mathrm{pH}$ of the enzyme was 7.0 in the $100 \mathrm{~mm}$ GTA buffer (Fig. 4A). When the enzyme activity was determined in various kinds of buffers, different optimum $\mathrm{pH}$ values were obtained: $\mathrm{pH} 8.0$ in Tris-HCl; pH 7.0 in sodium pyrophosphate buffer; and pH 7.5 in potassium or sodium phosphate buffer. Thus, the M. loti enzyme also showed an ionic environment-dependency like the Pseudomonas one (2). 

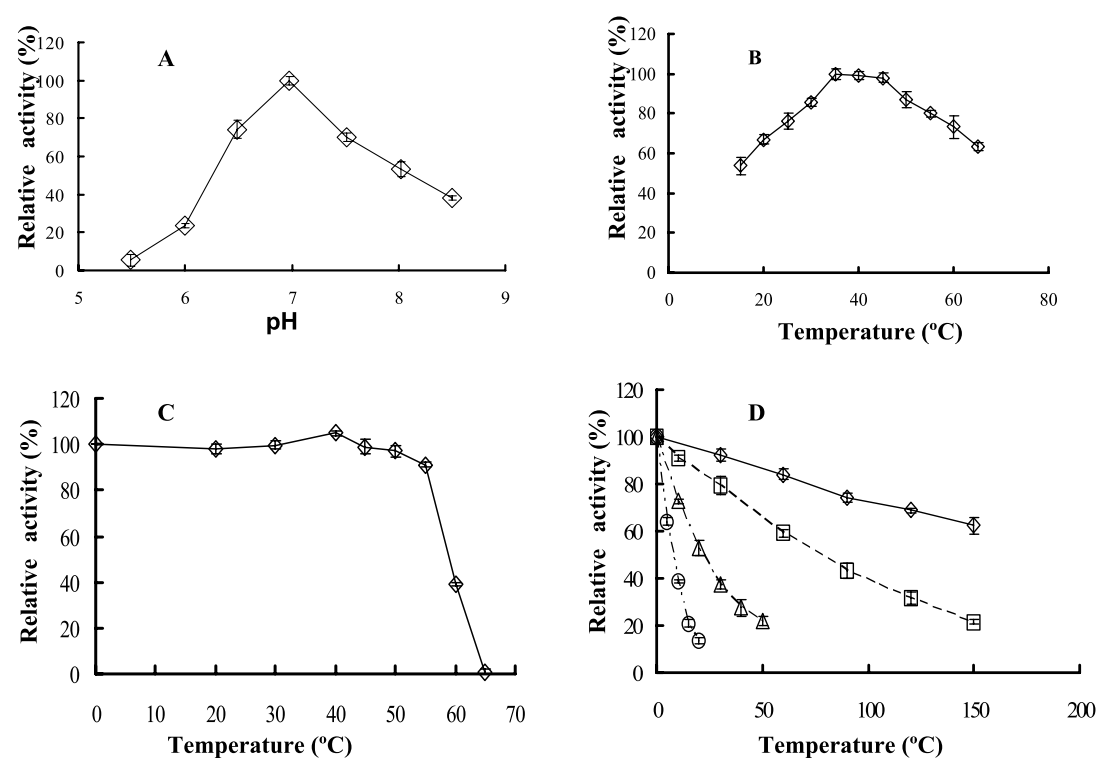

Fig. 4. Optimal $\mathrm{pH}$ and temperature, and temperature stability of AAMS amidohydrolase. A: the effect of pH on activity. The reaction was carried out in the GTA buffer ( $\mathrm{pH}$ 5.5, 6.0, 6.5, 7.0, 7.5, 8.0, and 8.5). B: the optimum temperature. The reaction was carried out in $0.1 \mathrm{~m}$ potassium phosphate buffer ( $\mathrm{pH} 7.0$ ) using $0.025 \mathrm{~mm}$ AAMS as a substrate. The activity was determined under the standard condition at $15,20,25,30,35,40,45,50,55,60$, and $65^{\circ} \mathrm{C}$. C: temperature stability. The enzyme solution was incubated at various temperatures for $10 \mathrm{~min}$. The activity of the enzyme incubated at $0^{\circ} \mathrm{C}$ was $100 \%$. D: the half lives at various temperatures. The enzyme was incubated at $50^{\circ} \mathrm{C}$ (diamonds), $55^{\circ} \mathrm{C}$ (squares), $58^{\circ} \mathrm{C}$ (triangles), and $60^{\circ} \mathrm{C}$ (circles).

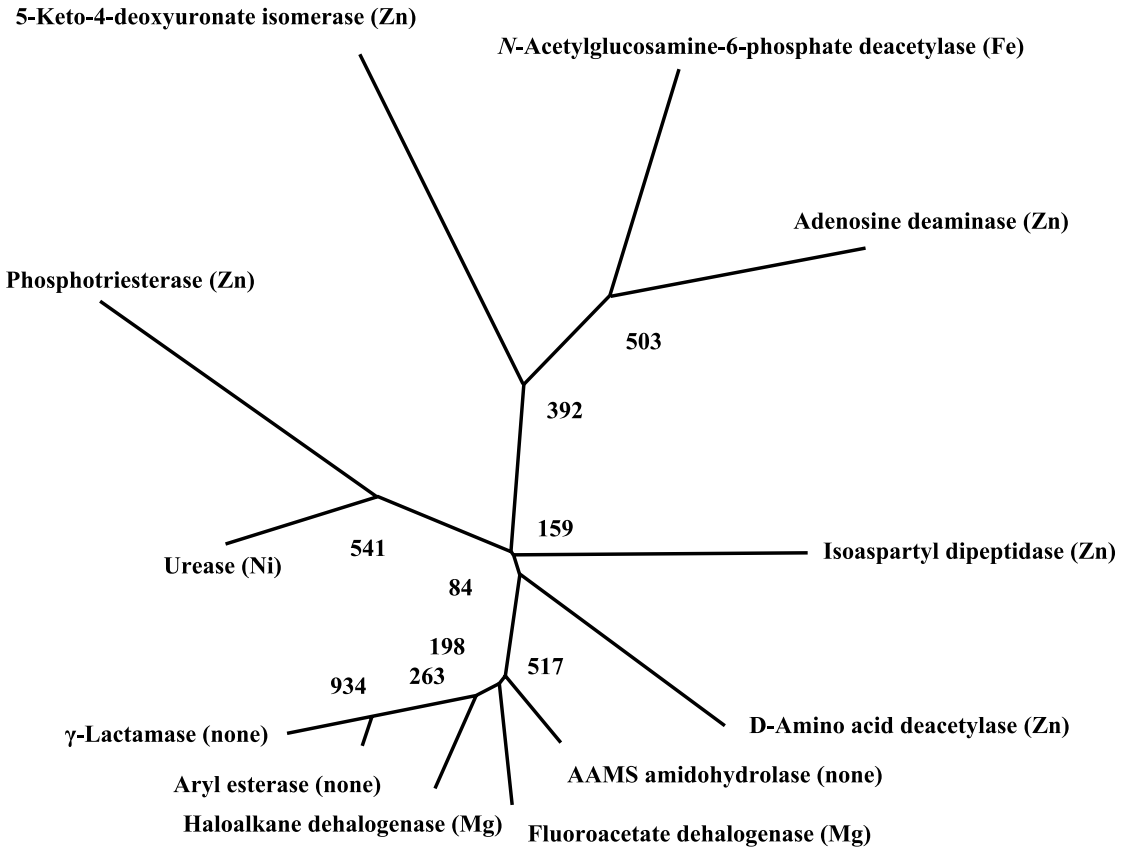

Fig. 5. Unrooted phylogenic tree of hydrolases. Amino acid sequences of eleven hydrolases, whose substrate specificity is characterized, were aligned by CLUSTALW, and an unrooted tree was determined. The numbers show bootstrap values. Metals required by them are also shown. PDB ID of the enzymes are $N$-acetylglucosamine-6-phosphate deacetylase, 1012; adenosine deaminase, 1A4M; D-amino acid deacetylase, 1M7J; aryl esterase, 1VA4; fluoroacetate deactylase, 1Y37; haloalkane dehalogenase, 1K5P; isoaspartyl dipeptidase, 10NW; 5-keto-4-deoxyuronate isomerase, 1XRU; $\gamma$-lactamase, 1HKH; phosphotriesterase, 1DPM; and urease, 1IE7.

The enzyme showed the maximum activity at $35^{\circ} \mathrm{C}$ in $0.1 \mathrm{M}$ potassium phosphate buffer ( $\mathrm{pH} 7.0$ ) (Fig. 4B). An Arrhenius plot of the optimum temperature gave $5,250 \pm 360 \mathrm{cal} \mathrm{mol}^{-1}$ of the activation energy for the hydrolysis of AAMS. The enzyme was stable at $50^{\circ} \mathrm{C}$ or lower for $10 \mathrm{~min}$ (Fig. 4C). The half life times of the enzyme were $193.6,77.3,21.6$, and $13.6 \mathrm{~min}$ at 50 , 55,58 , and $60^{\circ} \mathrm{C}$, respectively (Fig. 4D).

Typical Michaelis-Menten type kinetics were observed when the effect of the AAMS concentration on the reaction rate was examined. The $\mathrm{Km}$ and kcat for AAMS were $53.7 \pm 6 \mu \mathrm{M}$ and $307.3 \pm 12 \mathrm{~min}^{-1}$, respec- 
tively. Thus, the recombinant $M$. loti and Pseudomonas AAMS amidohydrolases shared the Km value, the ionic environment-dependency of optimum $\mathrm{pH}$, the metal ion-independency, and molecular weight of the subunit (3).

Under the assay conditions no activation or inhibition was observed upon addition of any one of the following metal ions: $\mathrm{Zn}^{2+}, \mathrm{Fe}^{2+}$, or $\mathrm{Ni}^{2+}$ (each $1 \mathrm{~mm}$ ). The enzyme activity was not affected when it was incubated at $30^{\circ} \mathrm{C}$ for $30 \mathrm{~min}$ in Buffer A containing $100 \mathrm{~mm}$ of EDTA. The results suggested that the enzyme contains no metal.

\section{Amino acid sequence comparisons}

The amino acid sequence of AAMS amidohydrolase was compared with other proteins in the PROSITE database. The sequence has no signature sequence of defined protein families, including amidohydrolase family proteins. Then, the sequence was analyzed by BLAST: the enzyme showed no identity to amidohydrolases so far reported. However, it showed low but significant (about 27\%) homology to fluoroacetate dehalogenase (PDB code, 1Y37) (15), haloalkane dehalogenase (1K5P) (16), and aryl esterase (1VA4) (17). Amino acid sequences of eleven hydrolases, whose substrate specificity is characterized, were aligned by CLUSTALW, and an unrooted tree was determined (Fig. 5). AAMS amidohydrolase made a cluster with fluoroacetate dehydrogenase, haloalkane dehalogenase, aryl esterase, and $\gamma$-lactamase, showing that these enzymes have low but significant amino acid sequence identity.

The alignment of the amino acid sequences of the enzymes in the cluster is shown in Fig. 3. Although overall identity in amino acid sequence is low, several amino acid residues are common in these enzymes, showing that they play essential roles in the catalysis of hydrolytic reaction. Interestingly, the distribution of secondary structures in AAMS amidohydrolase and aryl esterase is quite similar, suggesting that they have a similar tertiary structure. The aryl esterase, which is a metal-independent hydrolase, has the catalytic triad (Ser94, Asp222, and His251) (17) which is shown in red colors in Fig. 3. AAMS amidohydrolase has two corresponding amino acid residues (His258 and Ser106) but lacks one. Because AAMS amidohydrolase is also metal-independent as shown here, and should have the catalytic triad, aspartic acid residue corresponding to Asp222 in aryl esterase should exist. We are continuing our investigation into the tertiary structure and reaction mechanism of AAMS amidohydrolase.

\section{REFERENCES}

1) Nelson MJ, Snell EE. 1986. Enzymes of vitamin $B_{6}$ degradation. Purification and properties of 5-pyridoxic acid oxygenase from Arthrobacter sp. J Biol Chem 261: 15115-15120.

2) Nyns EJ, Zach D, Snell EE. 1969. The bacterial oxidation of vitamin $\mathrm{B}_{6}$ VIII. Enzymatic breakdown of $\alpha$ - $(\mathrm{N}$-acetylaminomethylene)succinic acid. J Biol Chem 244: 2601-2605.

3) Huynh MS, Snell EE. 1986. Enzymes of vitamin $B_{6}$ degradation. Purification and properties of two $\mathrm{N}$-acetyl- amidohydrolases. J Biol Chem 260: 2370-2383.

4) Kaneda Y, Ohnishi K, Yagi T. 2002. Purification, molecular cloning, and characterization of pyridoxine 4-oxidase from Microbacterium luteolum. Biosci Biotechnol Biochem 66: 1022-1031.

5) Yuan B, Yoshikane Y, Yokochi N, Ohnishi K, Yagi T. 2004. The nitrogen-fixing symbiotic bacterium Mesorhizobium loti has and expresses the gene encoding pyridoxine 4-oxidase involved in the degradation of vitamin $\mathrm{B}_{6}$. FEMS Microbiol Lett 234: 225-230.

6) Yoshikane Y, Yokochi N, Ohnishi K, Hayashi H, Yagi T. 2006. Molecular cloning, expression and characterization of pyridoxamine-pyruvate aminotransferase. Biochem J 396: 499-507.

7) Yokochi N, Nishimura S, Yoshikane Y, Ohnishi K, Yagi T. 2006. Identification of a new tetrameric pyridoxal 4dehydrogenase as the second enzyme in the degradation pathway for pyridoxine in a nitrogen-fixing symbiotic bacterium, Mesorhizobium loti. Arch Biochem Biophys 452: $1-8$.

8) Funami J, Yoshikane Y, Kobayashi H, Yokochi N, Yuan B, Iwasaki K, Ohnishi K, Yagi T. 2005. 4-Pyridoxolactonase from a symbiotic nitrogen-fixing bacterium Mesorhizobium loti: cloning, expression, and characterization. Biochim Biophys Acta 1753: 234-239.

9) Yuan B, Yokochi N, Yoshikane Y, Ohnishi K, Yagi T. 2006. Molecular cloning, identification and characterization of 2-methyl-3-hydroxypyridine-5-carboxylicacid-dioxygenase-coding gene from the nitrogen-fixing symbiotic bacterium Mesorhizobium loti. J Biosci Bioeng 102: $504-510$.

10) KDRI. 2008. The genome database for Rhizobia. Kazusa DNA Research Institute. [Online]. Available: http:// bacteria.kazusa.or.jp/rhizobase/about.html [accessed October 10, 2007]

11) Mizobata T, Akiyama Y, Ito K, Yumoto N, Kawata $Y$. 1992. Effects of chaperonin GroE on the refolding of tryptophanase from Escherichia coli. J Biol Chem 267: 17773-17779.

12) Shafqat J, Hoog JO, Hjelmqvist L, Oppermann UC, Ibanez C, Jornvall H. 1999. An ethanol-inducible MDR ethanol dehydrogenase/acetaldehyde reductase in Escherichia coli: structural and enzymatic relationships to the eucharyotic protein forms. Eur J Biochem 263: 305-311.

13) Bradford MM. 1976. A rapid and sensitive method for the quantitation of microgram quantities of protein utilizing the principle of protein-dye binding. Anal Chem 72: $248-254$.

14) Gill SC, Hippel PH. 1989. Calculation of protein extinction coefficients from amino acid sequence data. Anal Biochem 182: 319-326.

15) Omi R, Jitsumori K, Yamauchi $T$, Ichiyama $S$, Kurihara T, Esaki N, Kamiya N, Hirotsu K, Miyahara I. 2007. Expression, purification and preliminary X-ray characterization of DL-2-haloacid dehalogenase from Methylobacterium sp. CPA1. Acta Cryst F63: 586-589.

16) Streltsov VA, Prokop Z, Damborsky J, Nagata Y, Oakley A, Wilce MCJ. 2003. Haloalkane dehalogenase LinB from Sphingomonas paucimobilis UT26: X-ray crystallographic studies of dehalogenation of brominated substrates. Biochemistry 42: 10104-10112.

17) Cheeseman JD, Tocilj A, Park S, Schrag JD, Kazlauskas RJ. 2004. Structure of an aryl esterase from Pseudomonas fluorescens. Acta Cryst D60: 1237-1243. 